\title{
How to Avoid Speaking: The Experience of the Chora in Derrida's Denials and in Other Paradigms of Negativity
}

\section{Allaerts W*}

Biological Publishing A\&O, The Netherlands

*Corresponding author: Wilfried Allaerts, Biological Publishing A\&O, Nijverdal, The Netherlands.

\section{Commentary}

Volume 3 Issue 1

Received Date: December 30, 2019

Published Date: January 21, 2020

DOI: $10.23880 /$ phij-16000133

\section{Abstract}

Presumably, the starting point for this paper was formed by Jacques Derrida's lecture 'How to avoid speaking: Denials', given in 1986 in Jerusalem, a lecture devoted to the ancient doctrine of 'Negative Theology' (Apophasis). 'Presumably' means that I wasn't among the audience then - I was a philosophy student at the time - but nevertheless, fortuitously I found a book containing his lecture on my shelf. Although Derrida himself made abundantly clear that his work could not be interpreted as a restoration of negative theology, some critics have refuted Derrida's Denials based on the obligate inscription of the apophatic experience within the discursive logic of written language. In this paper a different route is followed, inspired by the so-called gesture of 'shame' in the work of Franz Kafka. Derrida's analysis recalls the importance of the experience of 'chora' (after Plato's Timaeus) in several paradigms of negativity. According to Derrida, the chora experience is an ill-defined, elusive mechanism, at best formulated as the occurring of an occurrence, the idea of having taken place. Throughout this paper, the notions of shamefulness and chora appear to follow Derrida's spur in a contemporary reflection on the catastrophic nature of the world of mankind in its present, shameful appearance. It thus becomes an alternative reading of the instruction 'How to avoid speaking', where shamefulness is the new paradigm of negativity. Moreover, Derrida's analysis invokes the darkest hollow for the faintest ray of light to become illuminative, similar to his ancient sources of inspiration. Also, Derrida's analysis is found a meaningful way to avoid confusion by religious or theological analogies in explaining our shameful relation to the planet, in times of climate change and pending natural catastrophes.

Keywords: Negative Theology; Derrida's Analysis; Chora; Avoidance; Gesture of Shame in Kafka's stories

\section{Outline}

1. Prolegomenon: on Paradigms of Negativity

2. Derrida's Experience of Chora in Denials

3. Propaganda, Kafka's Great Wall of China and other Stories
4. How not to Speak in Public

5. The Ecological Topos of Humanity

6. On Prayer and Anthropocentric Conversion 


\section{Philosophy International Journal}

\section{Prolegomenon: on Paradigms of Negativity}

The urge of an imperative, following our recent paper on the individual's role in climate awareness and responsibility ${ }^{1}$ and reflecting on Peter Sloterdijk's call (1947) for an ecological imperative ${ }^{2}$, crystallized into the first words of the present title 'How not to speak'. This title was a reminiscence of Jacques Derrida's (1930-2004) essay 'How to avoid speaking: Denials' ${ }^{3}$. In this essay (further on abbreviated as Denials), Derrida presented his lecture given in Jerusalem in 1986, following an invitation to speak about negative (apophatic) theology. Derrida herein invokes an imperative, which is inverted as a negative imperative: not a prohibition to speak or to avoid speaking, but an instruction to speak in silence ${ }^{4}$. Following the caveats of John D. Caputo ${ }^{5}$ and Shira Wolosky, reflecting Paul Ricoeur's (1974) “doubt that a negative theology can be based on Derrida's deconstructive program"6, we will take care not to rephrase Derrida's train of thoughts regarding the link between 'negative theology' and the Derridean notion of 'Différance'7,8; rather I will try to link up with a fertile merger of Derrida's Denials and the notion of shamefulness in Kafka's work (1883-1924), as explicitly pointed out in the correspondence between Gershom Sholem (1897-1982) and Walter Benjamin (18921940). Also, Sloterdijk's quasi-religious interpretation of the ecological imperative is envisioned as an alternatve frame of the mind ${ }^{2}$.

How to avoid speaking in terms of the reasons collected by Derrida ${ }^{3}$, namely the over-simplification and especially the denominative discourse typical for Western (scientific) rationality and some politics, as well as avoiding an affirmative science of 'negative theology' like in certain forms of atheism? ${ }^{9}$. Similar to Derrida, I refer to the Wittgensteinian insight as expressed in the Tractatus logico-philosophicus ${ }^{10}$ : "Of which we cannot speak, we should keep silent". To this well-known phrase, I would like to add Franz Kafka's impossibilities "either to write (in German)

1 W Allaerts (2019), pp: 9.

2 P Sloterdijk (2009), pp: 701.

3 J Derrida $(1987,1997)$.

4 "How while speaking avoid this or another way of speaking, (another way) of logic or rhetoric? How to avoid an unfair, wrong, deviant or misleading form? (...) Between two interpretations of <how not to speak?> the sense of care is to invert from <how to avoid speaking at all? $>$ to $<$ how to avoid speaking, when speaking well?> (...)". J Derrida (1997), pp: 43.

5 J D Caputo (1989), pp: 24, 30.

6 S Wolosky (1998), pp: 270.

7 J Derrida (1978).

8 J Derrida (1992).

9 de Botton A (2011).

10 Wittgenstein L $(1921,1922)$. and also not to write (in German), or not to write at all"11. Interestingly, Kafka's writings will stimulate a myriad of authors in formulating alternative 'paradigms of negativity' (see P3. Propaganda, Kafka's Great Wall of China and other Stories).

Derrida did write, however, and his discourse, paraphrased by himself and many others as a deconstructive discourse of 'denials', according to himself cannot be interpreted as a restoration of 'negative theology'3. Nevertheless, the relevance of negative theology is obvious in his work, where he builds upon the theological heritage of the early-christian Dionysius the Areopagite (PseudoDionysius) ( $1^{\text {st }}$ century AD) and medieval Meister Eckhart (Eckhart von Hochheim, 1260-1328), but also in his analysis of Plato's (428-347 BC) dialogue Timaeus ${ }^{12}$. According to Wolosky ${ }^{6}$, the relevance of deconstructive grammatology to negative theology, emerges "in an obverse way to those who would enlist Derrida within the order of theology". And, "instead of confirming the apophatic [ $\approx$ negative theology] intuition against language, Derrida's analysis implies that apophasis itself takes place within language and can never be disengaged from it" 6 . Obverse it may seem, but Derrida's analysis can be found instrumental too! The enigmatic relation between language and symbolization was already mentioned in our previous paper ${ }^{13}$. The question whether or not Derrida's situating of the place - where the apophatic experience takes place (in French avoir lieu) - can be adequately and unambiguously inscribed in language, will be the subject of the next paragraph ( $\mathbb{2} 2$. Derrida's Experience of Chora in Denials). On the other hand, also Wolosky refers to the writings of Gershom Scholem and Walter Benjamin as illuminating sources of the Judaic and Hebraic alternatives to the Greek/Hellenic heritage, and to that what "Derrida encounters across the border of language (which) may be called Hebraism"14. Derrida himself explains why he chose "not to speak about negativity or apophatic movements in the Jewish or Arabic traditions and leave this unmeasurable space empty" (except for a single footnote where he declares, autobiographically, what he is 'inside': "the Jew, the Arab.") ${ }^{15}$. The first paradigm of his deconstructive discourse was Greek, he declares, the second paradigm was Christian "without stopping to be still Greek", whereas the last paradigm would be "neither Greek nor Christian". With the latter paradigm, Derrida hesitantly follows Martin Heidegger (18891976) in his Greek-beyond Christian tradition, wherein

11 Cited from Kafka F, Briefe. (In: E Pawel [1984], pp: 259). See also our discussion of Walter Benjamin's Kafka lecture of 1934 in Allaerts W (2016).

12 Derrida J (1987, 1997), pp: 63.

13 Allaerts W (2019), pp: 5 (footnote 26).

14 Wolosky S (1998), pp: 274.

15 Derrida J (1987, 1997), pp: 62, 89. 


\section{Philosophy International Journal}

"Christian philosophy is regarded as a misunderstanding (Missverständnis), a square circle"16. Finally, Derrida ends his essay with the question, whether a theology would ever be possible when the "pure experience of praying" would become freed from "the contaminating act of writing, or the contamination of a code, of repeating, analogy or initiation"17. In analogy with this plea, we will explore the Derridean heritage of "How to avoid speaking" where it comes to a noncontaminated, uncorrupted relation to our planet ( $\$$ 5. The Ecological Topos of Humanity).

\section{Derrida's Experience of Chora in Denials}

"Are you going to continue reading your book? Or do you want to listen to our girls talk? Maybe, you could learn something from it, which you may not find in your book..."

I am reading Derrida's Denials, where he explains the socalled third genus of 'Chora' in Plato's Timaeus ${ }^{18}$, but a chorus of bystanders is trying to make me change my mind. In an era where reading books becomes an anachronism, Derrida talks about chora as "the anachronizing act of spatialization, the call for anachronism in each form of inscription" (referring to Descartes' idea of extension and Kant's pure, a priori forms of reason). It is difficult to give a definition of chora though, Derrida warns us, that isn't tainted by experience or by "an empirical relationship with the presence (either intellectual or sensible) of something present" ${ }^{\prime 19}$. Although it might evoke reminiscences of the chorus in ancient Greek drama, or of the round dance of this chorus, or of the people's dancing when celebrating the building of the Chinese Wall in Kafka's story ${ }^{20}$, it is none of these experiences but rather the occurring of the occurrence, the idea of actually having taken place (avoir lieu), as Derrida explains. But also the subsequent, selfevident associations with the notion of a 'metaphor' are called inadequate by Derrida, because the metaphor "like the complete rhetoric have grown out of Platonic metaphysics", and, therefore we should "fasten suspicion on the notion of metaphor". Plato, however, "did not have another word for $<$ chora $>(. . .)^{\prime 21}$. Notwithstanding that metaphorical language may be called inadequate - and often ambiguous too - , it may seem the only way to enlighten the dark space of the

16 Derrida J (1987, 1997), pp: 97: “When ich noch eine Theologie schreiben würde, wozu es mich manchmal reizt, dann dürfte in ihr das Wort $<$ Sein> nicht vorkommen". (Derrida here refers to a seminar presented by F Fédier and D Saatdjian (1980) in Possie, 13 and translated by J Greisch in Heidegger et la question de Dieu, p. 334.)

17 Derrida J (1987, 1997), p. 102.

18 Derrida refers to the 'Chora' as a triton genos in Plato's dialogue Timaeus (around 360 BC) (fide: J Derrida, ibidem, pp: 66).

19 Derrida J (ibidem), pp: 72.

20 Kafka F (1917, 1935), pp: 878.

21 Derrida J (ibidem), pp: 68-70. unspoken.

In the next paragraph (\$3. Propaganda, Kafka's Great Wall of China and other Stories), we will resume this metaphor notion: we will link up with Franz Kafka's metaphorical use(s) of the story of the Chinese Wall and other stories, and especially with the reading of Walter Benjamin $^{22}$ and the notion of 'shame' in these stories of Kafka. The difficulty of inscribing a notion of experiencing (of chora) in language without reducing this experience to the being of these experiences in terms of a collection of notions (albeit substances, extension(s) or Kant's pure $a$ priori forms) explained in language, is noted as Derrida's 'mission impossible' by others ${ }^{6}$. Similarly, this difficulty for Heidegger resulted in the philosophical position of avoidance to speak about the 'being' of God, also because "Faith doesn't need the notion of Being" ${ }^{\prime 2}$. Nevertheless, Derrida calls the philosophies of both Plato and Heidegger as problematic when it comes to the interpretation of the location (Ort) of chora and chorismus (in Heidegger's reading of Plato) and also of Heidegger's distinction between the (possibility of) revealing (Offenbarkeit) and the revelation (Offenbarung) of the God of theology ${ }^{24}$. (Besides, we have to point to the difficulty of translation of these notions from the German to the English language, because of the historic, linguistic, syntactic and other differences and limitations that are inherent to transferring notions from one to the other as quasi-identical within these languages) ${ }^{25}$.

Derrida finally refuses to answer the questions of accepting or denying the onto-theological inscription as paraphrased by Eckhart ("the Being of God is his forecourt [Vorbürg]", his 'being' is a 'beyond-being'), but rather returns to the riddle of the avoidance ${ }^{26}$. In the next paragraphs we will also return to the 'avoidance of speaking' in relation to the place of man and the world we live in, because of the socalled responsibility of mankind for the 'own' planet.

\section{Propaganda, Kafka's Great Wall of China and other Stories}

When seeing a sturdy, centennial oak next to a brush of ash, no soul on earth would call the old oak an ugly, fat tree, and, the ash tree, by comparison a youthful elegance. "Wir sind so gern in der freien Natur, weil diese keine Meinung über uns hat!", Friedrich Nietzsche wrote. And when the spring comes,

\footnotetext{
22 Benjamin W (1934).

23 Derrida J (ibidem), pp: 96-97, referring to Heidegger et la question de Dieu (see also note ${ }^{16}$ ).

24 Derrida J (ibidem), pp: 90-91.

25 Allaerts W (2019).

26 Derrida J (ibidem), pp: 98
} 


\section{Philosophy International Journal}

the children of the village make their dance round the old oak and sing, delightfully.

When it comes to the secular side of story-telling and communication, according to some, 'propaganda' should be regarded as a morally neutral form of 'idealization' ${ }^{27}$. Indeed, according to Alain de Botton, all forms of science, art, architecture, et cetera, are a form of 'propaganda'. And this shouldn't disturb us, he wrote in 2006, because "propaganda, as a way to spread information (or even a rumor only) about politics, religion or science" has no moral connotations ${ }^{28}$. Of course, this was written (some years, a decade at most) before the curse of fake-news swept the public opinion. In fact, the idea of art, (science) and architecture as being forms of an 'artistic idealization', according to de Botton, originated with the German poet, dramatist and idealist Johann Ch. Friedrich Schiller (1759-1805) ${ }^{29}$. The idealization implies that the reality doesn't coincide with the formal representation in the spoken or written language: it therefore has to be regarded as a negation of reality, or, at least, as a negation of the perfection of reality.

But, there is another way of 'artistic' use of language, that can be characterized as a way of negative speaking, or as a 'denial', as for instance witnessed in the enigmatic stories of Franz Kafka. The interpretation of Kafka's works has led to two ways of primary misunderstandings, namely the natural (psycho-analytical) and the super-natural (theological) interpretations, Walter Benjamin explains ${ }^{30}$. He especially criticizes the theological interpretation of Kafka's novel Das Schlo $\beta$ (1926) (by several authors) as a metaphor of (the site of) the 'divine grace' ${ }^{31}$. In 1934, in a letter to Gershom Scholem, Benjamin blames 'the unbearable attitude of theologians' that so far have dominated in all ways the reading

27 de Botton A (2006) see also our discussion in W Allaerts (2012).

28 de Botton A (2006), pp: 162.

29 Ch F Schiller J (1794) Über die ästhetische Erziehung des Menschen (fide A de Botton, 2006).

30 "Die nachgelassenen Reflexionen Kafkas, die im < Bau der Chinesischen Mauer> enthalten sind, geben Anla $\beta$, sich dieses Hergangs zu erinnern. Denn kaum war dieser Nachlaßband erschienen, als sich, gestützt auf seine Reflexionen, eine Deuting Kafkas hervortrat, die sich in deren Auslegung gefiel, um mit seinen eigentlichen Werken desto weniger Umstände zu machen. Zwei Wege gibt es, Kafkas Schriften grundsätzlich zu verfehlen. Die natürliche Auslegung ist der eine, die übernatürliche ist der andere; am Wesentlichen gehen beide - die psycho-analytische wie die theologische in gleicher Weise vorbei.(...)"(bold by WA)(W Benjamin, 1934, p. 16)

31 "Das erste Drittel dieser Interpretation kann man, seit Brod, wohl als Gemeingut der Kafka-Interpretation betrachten. In diesem Sinne schreibt z.B. Bernhard Rang: <Sofern man das Schlo $\beta$ als den Sitz der Genade ansehen darf, so bedeutet, theologisch gesprochen, eben dieses vergebliche Bemühen und Versuchen, da $\beta$ sich die Gnade Gottes nicht willkürlich und willentlich vom Menschen herbeiführen und erzwingen läßt. Die Unruhe und Ungeduld verhindert und verwirrt nur die Erhabene Stille des Göttlichen. >" (W Benjamin, 1934, p. 16) and interpretation of Kafka's work: "Each of Kafka's works is a victory of shame over the theological way of putting a problem"32. (Some interpreters have even pushed through, until using Kafka's evocation of misery in Das Schlo $\beta$ as an example of the Justification doctrine of Anselm of Canterbury [1033-1109] ${ }^{33}$. The (published) correspondence between Scholem and Benjamin, moreover, shows that both regarded "Kafka's world as the World of Revelation", although they clearly disagreed on the (theological) notion of the (obligate) unfulfilling of revelation ${ }^{34}$. For Benjamin, the significance of this revelation is like the role of the character Scheherazade, the story-teller in the One Thousand and One Nights tales: to procrastinate the execution of the beloved one, every night a new story has to be told ${ }^{35}$. Consequently, we may wonder: who is the beloved one in Kafka's stories?

Unlike the current interpretations of Kafka's work, Benjamin wonders about Kafka's own experiences. In contrast to the fairy-like, feminine figures, no real names of the worldly powers are given, or, Benjamin can't find any in Kafka's notes. What World is described in his novels and short stories? Benjamin subscribes to the notion that the novels of Kafka take place in a so-called swamp world (Sumpfwelt). Oblivion is its true power and ultimate, undulating appearance. For Benjamin, the best interpretation of Kafka's work is found in the 'Gestus', the incomprehensible gesture of his protagonists; and 'shame' is the strongest of these gestures (Gebärde) ${ }^{36}$. Shame, however, has a two-sided face, Benjamin explains. Kafka's shame is not only the intimate, personal shame for the other person, it is also "life and thoughts upon invitation of an (unknown) family". "Because of this unknown family, both humans and animals, he cannot be set free..." ${ }^{36}$. According to this reading, the position of man in this world can't be disengaged from his relation to

32 Letter from Benjamin to Scholem of 11 August 1934, In: Scholem G (1980, herausg.), 'Walter Benjamin Gershom Scholem Briefwechsel'. Frankfurt am Main: Suhrkamp Verlag, pp: 159-162

33 " $<$ Das alles $>$, sagt Denis de Rougemont, $<$ ist nicht der elende Stand des Menschen, der ohne Gott ist, sondern der Elendsstand des Menschen, der einem Gott verhaftet ist, den er nicht kennt, weil er Christum nicht kennt." (W. Benjamin, 1934, pp: 17). Denis de Rougement (1906-1985), born Neuchâtel in Switzerland, was one of the so-called non-conformists of the 1930s, standing the perils of totalitarianism from a Christian point of view.

34 "Deiner Leugnung dieses Aspektes - wenn ich es wirklich als eine Leugnung ansehen soll und es nicht nur ein Mißverständnis ist (...) - kann ich mich keineswegs anschließen. Die Unvollziehbarkeit des Geoffenbarten ist der Punkt, an dem aufs Allergenaueste eine richtig verstandene Theologie (wie ich sie mihr, in meine Kabbala versunken, denke und Du ihren Ausdruck ja gerade in jenem offenen Brief gegen Schoeps, den Du kennst, einigermaßen verantwortlich gegeben finden kannst) und das was den Schlüssel zu Kafkas Welt gibt, ineinanderfallen." (bold by GS)(Letter from Scholem to Benjamin, 17 July 1934, in: G Scholem [1980, herausg.], 'Walter Benjamin Gershom Scholem Briefwechsel.' Frankfurt am Main: Suhrkamp Verlag.

35 Benjamin W (1934), pp: 17.

36 Benjamin W (ibidem), pp: 18. 


\section{Philosophy International Journal}

the other living beings on the planet. Describing 'shame' for the unknown family, when embracing the living World around us, is like unveiling the beloved one without speaking its name. But this isn't a peaceful, harmonic world, even though formulated in the early 1930s, before the carnage of World War II took place and Benjamin - and thousands of thousands others - were killed. Scheherazade finally wasn't spared either. Kafka draws our attention to the animals, our unknown family on this planet Earth. Fear is the outer form of their 'thinking, "just like corruption is the outer form of Justice. Though it ruins progress, it is still the only hopeful thing" ${ }^{\prime 3}$.

The story of the Great Wall of China was written around 1917. Kafka's story starts as a kind of eye-witness report, the I-person was " 20 years old, when they started building the wall" ${ }^{\prime 38}$. Using this perspective, the story-teller entices us to join him in his story, what means: he is anachronistically drifting us from our ordinary, real world into a fairy-world. The anachronizing act resembles the experience of 'chora' in Derrida's analysis (see $\mathbb{P} 2$ ). And the author points at cues how to read this story. The story appears to contain living rules for the builders of the Great Wall, how to understand the instructions of the leaders, how to understand something pointless as a one-sided defense wall (so to speak facing the people of the North) - which 'in fact' appears to be "the foundations of a new Tour of Babel", which, by the way, didn't collapse by the confusion of tongues, but because of "the lack of good foundations"39 - and how to stop asking about pointless things. We ourselves can't understand the whole picture (metaphorically represented by the complex operation of the building of the Great Wall), but we cannot stop thinking either, because "this thinking is like the river floods, that return every spring" ${ }^{\prime 3}$.

The metaphorical reading of Kafka's story is obvious: although the story explicitly refers to the Chinese Empire - which was still in vogue in 1917 - and China would have played a decisive role in ending WW I in the East and future developments emanating the Versailles Treaty ${ }^{40}$, there is no reason why the ironic story-teller would not silently evoke the reminiscences of another 'empire'. For his purpose, as well as for ours, there is no need to explicitly call out that regime. Within the story, the story-teller appears as the laughing-stock, the messenger of 'old news', written in oldfashioned characters, revealing that his message is outdated and nobody hears the butt anymore. A loud laughter explodes. But, we know now (the historical significance of this irony).

\footnotetext{
37 Benjamin W (ibidem), pp: 21.

38 Kafka F $(1917,1935)$, pp: 877.

39 Kafka F (ibidem), pp: 880.

40 Elleman BA (2002).
}

The story reminds us of more recent story-telling experience in the People's Republic of China, like the stories told by the family-planning officials in the eighties and nineties, as revealed in a recent documentary ${ }^{41}$. From 1979 till 2014, a One Child Policy was harshly promoted in China, resulting in the killing of thousands of fetuses and forcing of mothers to abort their babies. Also babies born of poor families, e.g. in province Hunan, were taken away and sold to American adopting parents who believed the kids were orphans. Recently, the message of the family-planning officials has been upgraded to a 'Two Child Policy', but the propagandistic phraseology hasn't changed much, including the round dance performances of the story-tellers.

From a distant view, the irony of that performance couldn't be "ironed out of the fabric (of things)", as Morton would have put ${ }^{42}$; the irony is the mask that covers the face of shameful failure, in Kierkegaard's terminology, or it bears the signature of a collective gesture of shame, in the tradition of Kafka and Benjamin.

\section{How not to Speak in Public}

According to Derrida, the rhetoric aspect of 'speaking in public' follows the logic of Platonic metaphysics (see $\mathbb{P} 2$ ), albeit at war or in times of peace. The older generations may have learned that speaking in public should refrain from a number of obvious transgressions, like for reasons of decency, offensive language and other violent abuses. There is a tradition, say a cultural-historical relation between the negative side of 'speaking in public' and the notion of shame. Apart from the religious connotations of speaking and shaming in public, however, the present habits of public video monitoring and social communication technologies are constantly pushing the limits of the public domain. Moreover, the distinction between peace and wartime habits has turned into a twilight zone, for instance when slut-shaming of an individual citizen, like in the Monica Levinsky case, became a strategy for national political interests ${ }^{43}$. Traditionally, or in common wartime practice, slut-shaming literally is a collective, public process marking the end of war; and, it is directed against those that collaborated or slept with the enemy. We may wonder which enemy or which end-ofwar is marked in those recent political shaming practices;

41 The documentary 'One Child Nation' by Nanfu Wang and Jialing Zhang (2019).

42 Allaerts W (2019), pp: 6

43 The 'Independent counsel' in the Whitewater Controversy, Kenneth Starr declared in a television documentary that "the loyalty of Monica Levinsky ( ${ }^{\circ} 1973$ ) to (US President) Bill (William Jefferson) Clinton ( $\left.{ }^{\circ} 1946\right)$ was the biggest obstacle (in the attempts to impeach the President). This eight months of horror (to the national institutions) would be avoidable, if she wouldn't have been that loyal (...)" (from TV-documentary 'The Clinton Affair' [2018], directed by Blair Foster). 


\section{Philosophy International Journal}

but, it is obvious that the rhetoric of political reasoning may hardly constitute a morality guideline for the common people ${ }^{44}$. The distinction between times of war and peace even became more disturbing and misleading, after national states declared a 'war on terror' and martial law entered the civilian public affairs ${ }^{45}$.

Philosophically speaking, the morality rules defining human behavior may form a mer à boire, for instance, according to Bettina Stangneth ( ${ }^{\circ} 1966$, Hamburg), when following the deceptive logics of Thinking Evil ${ }^{46}$. Stangneth claims that the relationship between mind, ratio and morality can't be a simple deductive logic (resulting from a deceptive perception of morality), but follows from the evil characteristics present in the thinking process itself.

Whether or not the corruptibility of judgment - such as in academic thinking, according to Stangneth $\left({ }^{46}\right)$, or in the corruptibility of the Law ${ }^{37}$ - or the 'banality of evil' ${ }^{47}$ would construct a deceptive recipe for deviant thinking, at least in times of peace a common sense of 'thinking evil' is traceable in most - if not all - communities. The hope to create a better world, or the hope at least not to make our planet worse, in Stangneth's view is the essence of morality ${ }^{48}$; moreover, enlightenment is the moral requirement for each individual to make the right step-by-step approach into this collective imperative ${ }^{48}$. In the philosophy of Sloterdijk, a similar process of ascetic practicing - i.e. far away from public attention - is propagated, in order to achieve a so-called anthropocentric turn (Wende) $)^{2}$.

However, the propagation of ideas for good moral behavior are problematic, because they are necessarily inscribed into the language of the ruling media and national or world powers. Stangneth calls this the principle of theodicy ${ }^{49}$ : "the idea that the world of the good ones is on our side, because we have accepted the World's rule of power (and evil, or the world of the criminals is on the wrong side)". Historically, this idea indeed originated from the philosophical principle ${ }^{50}$ of the "benevolence of an allknowing God' that would be consistent with the existence of evil or suffering of the world, referring to the Augustinian theodicy, that would have been formulated as such in the writings of Augustine of Hippo (354-430 AD). For Jewish

\footnotetext{
44 Krutch JW (1962, 2004 ed).

45 Neiman S (2017).

46 Stangneth B (2016), p. 208-215.

47 Arendt H (1963).

48 Stangneth B (ibidem), pp: 224-229.

49 Stangneth B (ibidem), pp: 138.

50 After Gottfried Leibniz (1646-1716) in his work Essais de Théodicée (1734).
}

theologians and philosophers like Emmanuel Levinas (19061995), after the Holocaust, the problem of evil became a starting point for an opposite theory, called an anti-theodicy. And still others used the template for drawing a theory of justification based on the fundamental goodness of the cosmos, a cosmodicy so to speak ${ }^{51}$. For Stangneth ${ }^{49}$ and many others, the moral traditions of theodicy and anthropodicy coincide, and all these theories attempt to find a justification of morality based on a coherent world view ${ }^{52}$. In the next paragraph ( $\mathbb{P} 5)$, we will focus on the problematic nature of this world view in the light of recent climate change and other anthropogenic changes.

Whether or not the public blaming and shaming - as seen in the climate outcry of youngsters like Greta Thunberg $(\underline{2003} \text {, Sweden })^{53}$ - will result in a change of policy or political doctrine of the imputed governments, or in the public shaming of a new category of trespassers, they keep us in suspense. However, the new phenomenon of 'climate shaming' - as in the shaming of customers of cheap airway tourism and others - is already a social reality. Consequently, also the public speaking changes, in particular about our planet and our role in it, in the slip stream of the scientific alarming and media arousal regarding the most conspicuous events occurring in the present world's climate.

\section{The Ecological Topos of Humanity}

"Auch das Unnatürliche ist die Natur. Wer sie nicht allenthalben sieht, sieht sie nirgendwo recht" (J.W. von Goethe, Die Natur).

For Derrida, referring to Dionysius(see $\mathbb{1}$.Prolegomenon: on Paradigms of Negativity), to speak about theology cannot avoid the speaking of a topology of the divine being. Or, better, to speak "to God rather than about God", or to speak about 'unification with God', implies to speak "about the places, such as the altitude, the distance and also the proximity (of God)" 54 . But, according to Derrida, Dionysius also explained that "we do not have to pass through this distance that separates us, because the residence of the (divine) Trinity is 'everywhere and nowhere' $(. .$.$) "54. Indeed, like the idea of$ the goodness is beyond the being of things and transcends its being, the being of God, according to Dionysius, Meister Eckhart and other Christian theologians, is beyond the being of goodness, and even 'beyond being ${ }^{55}$. In the words of

\footnotetext{
51 Meiner C, Veel K (2012), pp: 243.

52 Hick J (1922-2012) in his work Evil and the God of Love $(1966,2010)$.

53 Greta Thunberg full speech at UN Climate Change COP24 Conference (2018, Katowice, Poland) (published: 15-12-2018).

54 Derrida J (ibidem), pp: 77.

55 Rumors of these teachings, ascribed to Eckhart (see J Derrida (ibidem), pp: 79), suggest these teachings caused his condemnation by Pope John XXII in 1329.
} 


\section{Philosophy International Journal}

Meister Eckhart, interpreted by Derrida, the description of the goodness of God "that looks like the light of a distant star (Quasi stella matutina)" ${ }^{\prime 56}$ has to be considered as a topology, a topological description and an adverbial (Quasi) quality of the divine word, such as the sermon accompanying the reading of the Scripture.

Similarly, some may argue that reading of the topology of humanity, the ecological topos of humans and of all the other living beings on the planet, as being a moral mission of mankind is also a religious, adverbial quality of the Word; for, "the other creatures on the planet don't need a sermon: they are already filled with God; they already are (like) a book (buoch)" ${ }^{\prime 57}$. However, Derrida himself abstains from the so-called problematic location of the 'chora of revelation' in the world of man (see $\mathbb{P} 2$. Derrida's Experience of Chora in Denials); so, when it comes to the 'unmeasurable space' of humanity, avoidance of speaking becomes his answer ${ }^{26}$.

But the planet itself has become a revelation of shame, the anthropogenic catastrophes shaking up our beliefs (in the normal order of things) constitute a paradigm of negativity in themselves. Moreover, the climate change debate, whetheror-not with an anthropogenic cause, has overtaken the discussions at the world's governmental fora; and, shaming about its economic ruling, and shaming about trading of carbon emission rights, trading of poverty derivatives and commodities, while temperatures and greenhouse gases are rising, income disparities become incalculable and basic supplies become scarce for large groups of economically disabled, all these complaints have turned into a novel Tour of Babel, a global confusion of tongues (see $\mathbb{P 3}$ ). The forgetfulness of economic theories, about our ecological origin, has even put the basic need of safe drinking-water as a primary right on the agenda of the United Nations, WHO and other global institutions ${ }^{58}$. Although great thinkers and poets like Johann Wolfgang von Goethe (1749-1832) declared that Nature is "both omnipresent outside and inside our bodies, as well as awkwardly strange to ourselves" 59 , we may indeed need a global declaration of human rights ${ }^{58}$ to reinforce the knowledge that, for all inhabitants of our planet, life isn't sustainable without the availability of water. Scientists in various disciplines, from biochemistry, microbiology and evolutionary biology towards ecology, the

56 In fact referring to the so-called morning star, the planet Venus, which in ancient times was regarded as a star "always residing at equal distance from the Sun (niemer verrer noch naeher)" (Derrida referring to Eckhart, cited in [Anonymous, or Pseudo-Hermes Trismegistus] Liber XXIV philosophorum, Derrida (ibidem) pp: 81).

57 Derrida J (ibidem), pp: 81

58 United Nations (2010), Resolution 64/292 and World Health Organization (2011), Resolution 64/24.

59 von Goethe JW $(1782,1932)$, pp: 924-926. most inclusive level in biology, have firmly established the waterborne origin of living organelles, evolving from the most primitive archaeobacteria and cyanobacteria towards the most complex creatures inhabiting the oceans. And, although since the early tetrapod vertebrates abandoned the aqueous environment for living on the land, their skin, lung and kidney adaptations still document their aquatic origin. Still, the failure to accept the undeniable necessity of water as a human right, as expressed not only by some economic giants ${ }^{60}$, reminds us of the ineradicable attempts to exchange primary needs for economic value, and the shamefulness of submerging the humble and weak in a variety of old and new forms of enslavement. It is the same collective shamefulness that has accompanied one of the oldest escapes from slavery (from the Nile delta) - although met with skepticism by some $^{61}$-, and that made the western civilizations hastily turn the more recent pages of history; and, it is shamefulness that reminds us that things are going terribly wrong with our planet, for instance when plastic garbage belts with almost continental proportions are discovered in all the gyres of our planet's oceans ${ }^{62}$.

\section{On Prayer and Anthropocentric Conversion}

One final return to Derrida's Denials we devote to his notion on the meaning of 'prayer' in the experience of theology, a notion that is missed, according to Derrida ${ }^{63}$, in the complete discussion of theology in the works of Heidegger. Derrida also analyses the interpretation of the Heideggerian notion of 'crossing out' the being of God, as given by JeanLuc Marion (인 Marion's so-called Christian interpretation of Heidegger, as well as from the onto-theological interpretation of his 'avoidance riddle' (see $\mathbb{P} 2$. Derrida's Experience of Chora in Denials). He concludes: "How to pray without the writing, the code, the repetition, (...) the initiation (of a prayer)?", in order to avoid any contamination or threat (caused by the analogy

60 Documentary 'Lords of Water' by Jérôme Fritel (2019) (Magnéto Presse/ARTE France/IDFA).

61 For an answer to the academically justified skepticism against the historicity of the biblical story, as found in Exodus 12-14, see e.g. Patterns of Evidence (2014).

62 The first garbage belt was discovered by oceanographer Charles Moore in 1997, when sailing with his catamaran through the North Pacific Gyre; see C Moore (2009).

63 There is never a prayer, not even an apostrophe in the rhetoric of Heidegger", see Derrida J (ibidem), p. 100.

64 Marion JL in Dieu sans l'être (1982) adopts this Heideggerian notion of 'crossing out' in a Christian tradition, by crossing out the name of God instead of the Heideggerian crossing out of the 'being' of God. Moreover, according to Derrida, Marion emphasizes the notion of 'the spur' of the gift of the (Christian) revelation, rather than the Heideggerian notion of 'crossroad', typographically represented by the crossing of the word 'Sein' without making the word invisible (kreuzweise Durchstreichung) (Derrida, ibidem, pp: 94-95). 


\section{Philosophy International Journal}

of phrases) from any of the religions or theologies ${ }^{65}$.

For Kafka, in the notes of his contemporary Gustav Janouch, "praying, (performing) art and scientific research are like flames firing up from the same fire (...); (...) in order to bring the scarcely surmised (from the dark regions of our unconscious roots) to the enlightened surface of our consciousness "66. It is a different state of mind than the self-declared, self-complacent, 'vertical' elevation from the 'banality' of our surrounding world, namely, in the phraseology of Sloterdijk, a state of mind that instead requires a day-to-day practicing in absolute, ascetic seclusion ${ }^{2}$. There is nothing that is really banal in the world around, but, most of the times, we may fail to see it, or fail to feel how nature explains itself to our senses ${ }^{25}$.

We cannot blame the polar bears (Thalassarctos maritimus) for invading a Russian village when the melting North Pole ice, together with the problem of garbage accumulation, forces them ${ }^{67}$. But our responsibility to safeguard the planet, to counter the effects of climate change and accumulation of garbage, also includes the frightened people living in the threatened villages, and not only the dangerous, but friendly looking bears. Ecologically speaking, the polar bears are at the top of the food chain, they may be one of the few species that consider humans as 'food'. From a safe distance, we sometimes enjoy the softening television images of bears, the more so when looking at their pups; but that is not how natural biodiversity deploys itself in the pristine, outdoor environments. The narrow top of the ecological pyramid implies a broad base that is unimaginably larger than our scientific methods and imagination allow us to think of, or than the collection of images shown in the popular media: of charming, fluffy or colorful species selected by the television makers. Nature doesn't write to us with the typography of our best-selling images, but with the humble, tiny creatures from sea algae and bacteria to the also colorful Lichens that cover trees and rocks, at least when air pollution is not causing their death. It is a humbling thought that these creatures will remain present on planet Earth, if and when mankind eventually has eliminated its own conditions for sustainable life. However, for the vast majority of people inhabiting this planet, the pristine natural habitats are simply too small to harbor them: we are literally collectively excluded from living in the Earth's natural reserves. This probably could become the saddest consequence of having passed the tipping point of the anthropogenic conversion of our planet. The civilization and demographic development of the world population already have forfeited a natural

65 Derrida J (ibidem), pp: 102.

66 Janouch G (1968) (see also our discussion of the authenticity of this source in W Allaerts, 2016).

67 Becker R (2019). way back. All the more important is the anthropocentric conversion of ourselves - in contrast to the anthropogenic conversion of this planet -, defined as: to experience, when looking, feeling or enduring the mechanisms of nature deploying itself, in its most simple or primitive life forms, to us, when allowing a receptive state of mind. And this may indeed constitute a hopeful challenge ahead.

Meanwhile, in the Australian rain forest, the male jumping spiders of Jotus remus wave their leg paddles to attract and court their female partners (National Geographic Video 2016, see also BBC series 'Seven worlds, one planet. Australia').

\section{References}

1. Allaerts W (2012) From post-functional method to bilogical: Background, trivial explicitations and malignant anathemata. bi-logical 4(2): 41-50.

2. Allaerts W (2016) Walter Benjamin: facing the Angel of Oblivion. Between the Storms of Progress and the Ruins of History. bi-logical 6(1): 44-55.

3. Allaerts W (2019) Into the Origins of the Inside-Outside Debate: Rediscovering Smell/Odor and Tracking the Steps of Nietzsche, Proust and Timothy Morton. Philosophy International Journal 2(2): 000129.

4. Arendt H (1963) Eichmann in Jerusalem. A Report on the Banality of Evil. New York: Viking Press (Penguin Classics series).

5. Becker R (2019) Why polar bears invaded a Russian village. A combination of climate change and garbage.

6. Benjamin W $(1934,1977)$ Franz Kafka. Zur zehnten Wiederkehr seines Todestages. In: Tiedemann R, Schweppenhäuser $\mathrm{H}$ (Eds.), Walter Benjamin Gesammelte Schriften II, 1, herausg. Frankfurt am Main: Suhrkamp Verlag.

7. Caputo JD (1989) Mysticism and Transgression: Derrida and Meister Eckhart. In: Silverman HJ (Ed.), 'Derrida and Deconstruction', New York: Routledge.

8. de Botton A $(2006,2011)$ The Architecture of Happiness. (Dutch transl J Noorman [2011] 'De Architectuur van het Geluk'. Amsterdam: Amstel Uitgevers BV).

9. de Botton A (2011) 'Religion for Atheists. A nonbeliever's guide to the uses of religion'. (Dutch transl. J Noorman (2011) Religie voor atheïsten. Een heidense gebruikersgids. Amsterdam: Uitgeverij Atlas).

10. Derrida J (1978) Writing and Difference. Chicago: The University of Chicago Press. 


\section{Philosophy International Journal}

11. Derrida J (1987) Comment ne pas parler - Dénégations. In: Derrida J (Ed.), Psyché - Inventions de l'autre, Paris: Éditions Galilée. (Dutch transl. R Sneller (1997) Hoe niet te spreken: Dionysius, Eckhart en de paradigma's van negativiteit, Kampen / Kapellen: Kok Agora / Pelckmans.)

12. Derrida J (1992) Post-Scriptum: Aporias, Ways and Voices. In: Coward H, Foshay T (Eds.), Derrida and Negative Theology. Albany: State University Press of New York, pp: 283-323.

13. Elleman B (2002) Wilson and China: A Revised History of the Shandong Question. New York: Routledge.

14. Fritel J (2019) 'Lords of Water' (Documentary). Production Magnéto Presse, ARTE France, IDFA.

15. Goethe JW von $(1782,1932)$ Die Natur. In: Goethes Werke (mit einer Einführing von Gerhart Hauptmann), Band I, (Berlin: Verlag Th Knaur, 1932 (Ed), pp: 924-926.

16. Hick J $(1966,2010)$ Evil and the God of Love. $2^{\text {nd }}$ (Edn.), Palgrave MacMillan, NewYork, London.

17. Janouch G (1968) Gespräche mit Kafka. Frankfurt am Main: S Fischer Verlag.

18. Kafka F (1917) The Great Wall of China. In: Brunt N (Ed.), (1935) Franz Kafka: Sämtliche Erzählungen, Berlin: Schocken Verlag (Dutch Transl. 1982 ed).

19. Krutch JW (1962, 2004 ed) Walden and Other Writings by Henry David Thoreau. Bantam Books (Classic edition), New York.

20. Leibniz G (1734) Essais de Théodicée sur la bonté de Dieu, la liberté de l'homme et l'origine du mal. Amsterdam (Engl. transl. Huggard EM (1985), Theodicy: Essays on the Goodness of God, the Freedom of Man and the Origin of Evil. Lasalle (Illinois, USA): Open Court).

21. Marion JL (1982) Dieu sans l'être. (Engl. transl. TA
Carlson (1995) God Without Being, Chicago: University of Chicago Press)

22. Meiner C, Veel K (2012) The Cultural Life of Catastrophes and Crises. Cumberland (Rhode Island, USA): Walter de Gruyter, pp: 330.

23. Moore C (2009) Capt. Charles Moore on the seas of plastic. TED (Lectures), ideas worth spreading.

24. Neiman S (2017) Resistance and Reason in Post-truth Times. Ecowin by Benevento Publishing/ Lemniscaat bv, Rotterdam.

25. Patterns of Evidence (2014) 10 Artifacts Pointing to the Historicity of Exodus Events.

26. Pawel E (1984) The Nightmare of Reason. New York: Farrar, Straus \& Giroux. (Dutch Transl. J Perry (1988) 'Het Leven van Franz Kafka'. Amsterdam: van Gennep).

27. Sloterdijk P (2009) Du mußt dein Leben ändern. Frankfurt am Main: Suhrkamp.

28. Stangneth B (2016) 'Böses Denken'. Reinbek bei Hamburg: Rowohlt Verlag Gmbh (Dutch transl. R van Veen (2017) 'Het Kwade Denken', Amsterdam / Antwerpen: Uitgeverij Atlas Contact).

29. United Nations (2010) Human right to water and sanitation. UN General Assembly: Resolution 64/292.

30. Wang N, Zhang J (2019) One Child Nation (Documentary).

31. World Health Organisation (2011) Drinking-Water, Sanitation and Health (WHA64.24). World Health Assembly: agenda item 13.15 .

32. Wittgenstein L $(1921,1922)$ Tractatus logicophilosophicus. Logisch-Philosophische Abhandlung.

33. Wolosky S (1998) An "Other" Negative Theology: On Derrida's "How to Avoid Speaking: Denials". Poetics Today 19(2): 261-280. 